\title{
Pilus-mediated adsorption of Pseudomonas syringae to the surface of host and non-host plant leaves
}

\author{
Martin Romantschuk, ${ }^{1 *}$ Eeva-Lisa Nurmiaho-Lassila, ${ }^{2}$ Elina Roine ${ }^{1}$ and Anu Suoniemi ${ }^{1}$ \\ Departments of ${ }^{1}$ General Microbiology and ${ }^{2}$ Electron Microscopy, PO Box 41, Mannerheimintie 172 , \\ $\mathrm{SF}-00014$ University of Helsinki, Finland
}

(Received 4 February 1993; revised 5 April 1993; accepted 13 April 1993)

\begin{abstract}
Adsorption of cells of a variety of Pseudomonas syringae pathovars to the leaf surface of host and non-host plants was measured. The strains used were sensitive to the pilus-specific bacteriophage $\phi 6$. Phage-resistant non-piliated mutants were isolated and found to have reduced ability to adsorb to plant surfaces. The pilus-mediated adsorption was not host-specific. Piliated strains adsorbed well to both host and non-host plants. Scanning electron microscopy of the $P$. syringae pathovar syringae strain R32 and the pathovar phaseolicola strain HB1OY revealed a difference between these strains in the distribution of the bacterial cells over the lower bean leaf surface. $P$. syringae pv. syringae spread evenly over the leaf surface whereas $P$. syringae pv, phaseolicola adsorbed preferentially to the stomata. No such localization was observed on chloroform-treated leaves, where the cells of both pathovars were evenly distributed. Adsorption of bacteria to leaf disks was independent of divalent cations, and no specific ionic conditions were required.
\end{abstract}

\section{Introduction}

In the interaction between bacteria and their host plants, attachment has received attention mainly in cases where initial attachment is absolutely required for invasion of the host plant tissue, as in the case of Agrobacterium and Rhizobium (Matthysse, 1987; Romantschuk, 1992; Smit et al., 1989; Smit \& Stacey, 1990). Attachment has not been extensively studied as an epiphytic or rhizosphere fitness factor, however.

Interest in genes and traits required for epiphytic colonization by bacteria is relatively recent. The molecular biology of epiphytic growth has received increasing attention since the finding that some epiphytes function as ice nucleation centres (Lindow, 1983; Maki et al., 1974), and because of the potential for using epiphytes as biocontrol agents of plant disease and frost damage (Blakeman \& Fokkema, 1982; Lindow, 1986; Upper, 1991).

Pseudomonas syringae strains are divided into pathovars according to the plant species they infect. However, non-pathogenic strains have also been isolated. Both non-pathogenic and pathogenic strains of this species are a common component of the epiphytic bacterial flora of

*Author for correspondence. Tel. +35804735415; fax +3580 4735 426; e-mail internet ROMANTSCHUK@CC.HELSINKI.FI. healthy plants (Hirano \& Upper, 1983). Thus, the species is an opportunistic pathogen with an epiphytic growth phase on the surfaces of plants. An important feature in the ecology of the bacterium is the ability of many strains to function as ice-forming nuclei at relatively high subzero temperatures, a phenomenon widely studied in terms of its molecular basis and ecological implications (Lindow, 1983; Warren \& Wolber, 1991). The ecology, such as pattern of epiphytic growth and spread of the bacterium under field conditions, has also been studied (Butterworth \& McCartney, 1991; Hirano \& Upper, 1983; Lindemann et al., 1982; Malvick \& Moore, 1988; O'Brien \& Lindow, 1989). Hirano et al. (1991) found that heavy rain induced rapid growth of $P$. syringae strains on bean leaves while simultaneously washing away high numbers of other bacteria. The basis for the ability of the bacterium to colonize plants has not been widely studied, although the ability to withstand drought, resistance to UV-irradiation, and the ability to scavenge nutrients on the plant surface have been implied (Blakeman, 1991). The ability to resist removal from the plant surface by physical forces such as rain, however, has received little attention. Thus, the structures of Pseudomonas syringae cells involved in adsorption to solid surfaces have remained largely unexplored.

The bacteriophage $\phi 6$ isolated from $P$. syringae pv. phaseolicola (Vidaver et al., 1973) adsorbs to bacterial 
Table 1. Bacterial strains used

\begin{tabular}{|c|c|c|c|c|c|c|}
\hline Strain & & Host plant & $\begin{array}{c}\text { Sensitivity } \\
\text { to phage } \\
\phi 6\end{array}$ & Piliation* & Motility & Sourcet \\
\hline \multicolumn{7}{|l|}{ Pseudomonas syringae } \\
\hline \multirow[t]{5}{*}{ pv. phaseolicola } & HB10Y (HB)] & & + & + & - & Vidaver et al. (1973) \\
\hline & ER2.5 & & - & - & - & This study \\
\hline & ER2.5.31 & & + & $+t$ & - & This study \\
\hline & MP0.16 & & - & - & - & $\begin{array}{l}\text { Romantschuk \& Bamford } \\
\text { (1985) }\end{array}$ \\
\hline & MP22.14 & Bush bean & - & ++ & & $\begin{array}{l}\text { Romantschuk \& Bamford } \\
\text { (1985) }\end{array}$ \\
\hline \multirow[t]{3}{*}{ pv. syringae } & $\mathrm{R} 32$ & (Phaseolus vulgaris) & + & + & + & $\begin{array}{l}\text { K. Rudolf, Georg-August- } \\
\text { Universität, Göttingen, } \\
\text { Germany }\end{array}$ \\
\hline & R32.4 & & - & - & + & This study \\
\hline & R32.13 & & - & ++ & + & This study \\
\hline \multirow{2}{*}{ pv. phaseolicola } & 2740 & & + & + & + & ICMP \\
\hline & $2740 \mathrm{R}$ & & - & - & + & This study \\
\hline \multirow[t]{2}{*}{ pv. coronafaciens } & 3113 & Oat & + & + & + & ICMP \\
\hline & $3113 \mathbf{R}$ & (Avena sativa) & - & - & + & This study \\
\hline \multirow[t]{2}{*}{ pv. lachrymans } & 829 & Cucumber & + & + & + & ICMP \\
\hline & $829 \mathrm{R}$ & (Cucumis sativus) & - & - & + & This study \\
\hline \multirow[t]{2}{*}{ pv. tomato } & 2841 & Tomato & + & + & - & ICMP \\
\hline & $2841 \mathrm{R}$ & (Lycopersicon & - & - & - & This study \\
\hline \multirow[t]{2}{*}{ pv. tomato } & 9315 & esculentum) & + & + & + & ICMP \\
\hline & $9315 R$ & & - & - & + & This study \\
\hline \multirow[t]{2}{*}{ pv. syringae } & 457 & Apple & + & + & - & ICMP \\
\hline & $457 \mathrm{R}$ & (Malus $\times$ domestica) & - & - & - & This study \\
\hline
\end{tabular}

*Wild-type piliation, + ; non-piliated, - ; super-piliated (more than the respective wild-type), ++ .

†ICMP, International Collection of Microorganisms from Plants, Auckland, New Zealand.

pili (Bamford et al., 1976; Vidaver et al., 1973). Nonpiliated variants are easily obtained by selection for phage-resistance (Cuppels et al., 1979; Romantschuk \& Bamford, 1985), but super-piliated phage-resistant mutants have also been isolated (Romantschuk \& Bamford, 1985).

Piliated strains of $P$. syringae pv. phaseolicola $\mathrm{HB} 10 \mathrm{Y}$ were earlier shown to adsorb preferentially to the stomata of bean leaves, whereas the adsorption of nonpiliated mutants was significantly reduced compared to the piliated strains. The ability of bacterial suspension of the piliation-mutants to cause symptoms when infiltrated into bean leaf tissue was unaffected, but in sprayinoculation experiments the presence of pili correlated positively with frequency of infection (Romantschuk \& Bamford, 1986).

Bacterial tissue-specific adsorption mediated by pili or fimbriae has been indicated in many animal diseases (Jann \& Jann, 1990). Also plant-specific pathogenic and non-pathogenic bacteria have been shown to bind to plant cells in liquid culture or to intact or wounded plant tissue (Romantschuk, 1992). In several cases bacterial adhesins have been identified or suggested, as for Rhizobium leguminosarum (Smit et al., 1989), Agrobacterium tumefaciens (Matthysse, 1983), Klebsiella and Enterobacter (Haahtela et al., 1985), Pseudomonas solanacearum (Young \& Sequeira, 1986), and $P$. syringae (Romantschuk \& Bamford, 1986).

Here we compare adsorption characteristics of different strains and pathovars of $P$. syringae to host and non-host plants.

\section{Methods}

Bacterial strains and growth conditions. Bacteria were grown in Luria-Bertani (LB) medium (Sambrook et al., 1989) or King's medium B (King et al., 1954) at $28^{\circ} \mathrm{C}$ with aeration. Solid media contained $1.5 \%(\mathrm{w} / \mathrm{v})$ agar. Bacterial strains are listed in Table 1.

Host plants. Bush bean (Phaseolus vulgaris) ev. Red Mexican (UI36) was used as the susceptible host for the bean pathogens. Cucumber (Cucumis sativus) cv. Sandra, tomato (Lycopersicon esculentum) cv. Selandia, oats (Avena sativa) cv. Puhti and apple (Malus $\times$ domestica) were used as the host plants for their respective pathovars.

Phage adsorption assay. Expression of phage $\phi 6$-specific pili of the bacterial strains was recognized either by measuring cell-associated radioactivity after incubation of a bacterial suspension with radioactively labelled phage or by measuring ability of a bacterial culture to remove plaque forming units from a suspension (Romantschuk \& Bamford, 1985). The radioactively labelled phage was obtained from Dr Dennis Bamford, Department of Genetics, University of Helsinki, Finland.

Radioactive-labelling of bacteria. Bacterial suspensions from overnight cultures in M9 medium (Sambrook et al., 1989) containing 0.4\% 
glucose and $0.1 \%$ yeast extract were diluted $1: 20$ in $2 \mathrm{ml}$ of the same medium supplemented with $20 \mu \mathrm{Ci}(74 \mathrm{kBq})\left[{ }^{35}\right.$ S]methionine (Amersham, SJ1015). Tubes were incubated with shaking at $21{ }^{\circ} \mathrm{C}$ for $15 \mathrm{~h}$. Incorporation was approximately $80 \%$, and the specific activity of the cells $1-2 \times 10^{-3}$ c.p.m. per c.f.u. depending on the age of the label used. The cells were pelleted and resuspended in $0.3 \times \mathrm{M} 9$ glucose fomitting divalent cations) and kept on ice.

Bacterial adsorption assay. Adsorption was measured essentially as described earlier (Romantschuk \& Bamford, 1986). Young trifoliate leaves of Red Mexican bean were treated with $0.1 \%$ Triton X-100, chloroform or pure water for $10 \mathrm{~min}$ followed by rinsing in an excess of water for $30 \mathrm{~min}$. The hydrophobicity of the leaf surface was determined as described by Bunster et al. (1989), using a video camera to record the shape and contact angle of the droplets. Leaf disks $(12 \mathrm{~mm}$ diam.) were excised with a cork bore and were submerged in $2 \mathrm{ml}$ of the adsorption medium $(0.3 \times$ M9 salts with $0.1 \%$ glucose, and various salts as mentioned in the Results) in $4 \mathrm{~cm}$ diam. tissue culture dishes. For measurement of adhesion efficiency, radioactively labelled bacteria were added at a concentration of $2 \times 10^{7}$ cells $\mathrm{ml}^{-1}$. The dishes were agitated $(60$ r.p.m.) in a shaker for $60 \mathrm{~min}$ after which the leaf disks were rinsed with the same agitation for $10 \mathrm{~min}$ in $10 \mathrm{ml} 10 \mathrm{~mm}-$ potassium phosphate buffer, $\mathrm{pH} 7 \cdot 5$, (washing buffer). Radioactivity was measured on an LKB-Wallac liquid scintillation counter.

Electron microscopy. Samples for scaming electron microscopy were prepared either as in the adsorption assay, but with a higher concentration of bacteria $\left(\sim 1 \times 10^{9} \mathrm{cells} \mathrm{m}^{-1}\right)$, or using a static adsorption incubation as described by Romantschuk \& Bamford (1986). After $1 \mathrm{~h}$ incubation, the specimens were prepared as described by Nurmiaho-Lassila et al. (1991). The leaf disks were prefixed in 3\% (v/v) glutaraldehyde in $0.1 \mathrm{M}$-sodium phosphate buffer $(\mathrm{pH} 7 \cdot 2$ ) for $3 \mathrm{~h}$ at room temperature and then washed three times with the same buffer, post-fixed for $2 \mathrm{~h}$ in buffered $1 \%(\mathrm{w} / \mathrm{v})$ osmium tetroxide, dehydrated in a graded series of ethanol and dried in a critical point drying apparatus. The specimens were coated with gold and observed with a Jeol JSEM-820 scanning electron microscope operating at $10 \mathrm{keV}$.

Isolation of non-piliated and super-piliated bacterial mutants. Bacteriophage $\phi 6$ was isolated from and grown on $P$. syringae pv. phaseolicola HB10Y (Vidaver et al., 1973). Some of the phage-sensitive bacterial strains used in this study produced small and/or turbid plaques by phage grown on the original host. For these strains spontaneous host range mutants producing clear plaques were selected by two rounds of single plaque isolations, followed by growth and purification of the phage (Romantschuk \& Bamford, 1981). Bacteria with an altered pilus expression were obtained by selection for phage $\phi 6$ resistance, and the presence of pili was determined with radioactively labelled phage (Olkkonen \& Bamford, 1987), or by measuring the ability of the bacterium to remove phage particles from suspension (Romantschuk \& Bamford, 1981). In the case of the original host, P. syringae pv. phaseolicola HB10Y, both spontaneous and $\operatorname{Tn} 5$ transposon (E. Roine, unpublished; Selvaraj \& Iyer, 1983) mutants of the bacteria were used, whereas the piliation mutants of the other strains were spontaneous.

\section{Results}

$P$. syringae pv. phaseolicola strain $\mathrm{HB} 10 \mathrm{Y}(\mathrm{HB})$ and $P$. syringae pv. syringae strain R32 pathogenic for bean, express pili that function as receptors for the original (wild-type) phage $\phi 6$. Romantschuk \& Bamford (1981, 1985 ) isolated phage-resistant spontaneous mutants of HB. Phage-resistant mutants of the other strains used were isolated in a similar fashion (Table 1). Out of sixteen $\phi 6$ resistant R32 mutants tested for phage adsorption, fifteen were non-piliated and one, named R32.13, expressed a higher degree of piliation ('superpiliated') than the wild-type phage-sensitive strains as measured by phage-adsorption (Table 2 ). Only mutants showing no phage adsorption, indicating a lack of pilus production were isolated from the other pathovars used.

In an effort to characterize pilus production of the original phage $\phi 6$ host $P$. syringae pv. phaseolicola HB10Y, transposon mutagenesis was performed using the conjugative $\mathrm{Tn} 5$-carrying plasmid pGS9 (Selvaraj \& Iyer, 1983) as a suicide vector. The transposon mutant ER2.5 and the spontaneous mutant MP0.16 were used in this study as the non-piliated HB mutants. Pilus production in both strains was restored with the same cosmid from a genomic $P$. syringae pv. phaseolicola library made by Ehrenshaft \& Mills (1985). As indicated by phage-adsorption ability (Table 2), the complemented strain ER2.5.31 expresses a higher degree of piliation than the wild-type $\mathrm{HB}$ and is here used as the superpiliated HB variant along with the mutant strain MP12.14. Characterization of transposon mutants and genes involved in pilus production will be described elsewhere (E. Roine, unpublished).

\section{Bacterial leaf surface adsorption}

Adsorption of bacteria to the leaf surface was studied by (i) assaying adsorbed radioactivity using ${ }^{35}$ S]methioninelabelled bacteria, and (ii) scanning electron microscopy. Leaves rinsed only in water prior to the adsorption incubation were difficult to submerge, resulting in a

\section{Table 2. Adsorption of $\phi 6$ to piliated and non-piliated} strains of Pseudomonas syringae

\begin{tabular}{llcc}
\hline \hline \multicolumn{1}{c}{ Strain } & Properties & $\begin{array}{c}\text { Percentage } \\
\text { adsorption* }\end{array}$ & Piliation $\dagger$ \\
\hline $\begin{array}{l}\text { P. syringae pv. } \\
\text { phaseolicola }\end{array}$ & & & \\
HB10Y (HB) & Wild-type $/ \phi 6^{\mathrm{S}}$ & 45 & + \\
ER2.5 & Tn5/ $\phi 6^{\mathrm{R}}$ of $\mathrm{HB}$ & 4 & - \\
ER2.5.31 & ER2.5 & 75 & ++ \\
& complemented $/ \phi 6^{\mathrm{S}}$ & & \\
P. syringae pv. & & & + \\
syringae & & & - \\
R32 & Wild-type $/ \phi 6^{\mathrm{S}}$ & 55 & ++ \\
R32.4 & $\phi 6^{\mathrm{R}} /$ spont. & 8 & + \\
R32.13 & $\phi 6^{\mathrm{R}} /$ spont. & 82 & + \\
\hline \hline
\end{tabular}

* Phage adsorption was measured using radioactively labelled phage.

$\dagger$ The piliation of the wild-type strain was defined as + , while - and $t+$ denote no piliation or more than the wild-type, respectively, as measured by phage adsorption rate and by electron microscopy (not shown). 


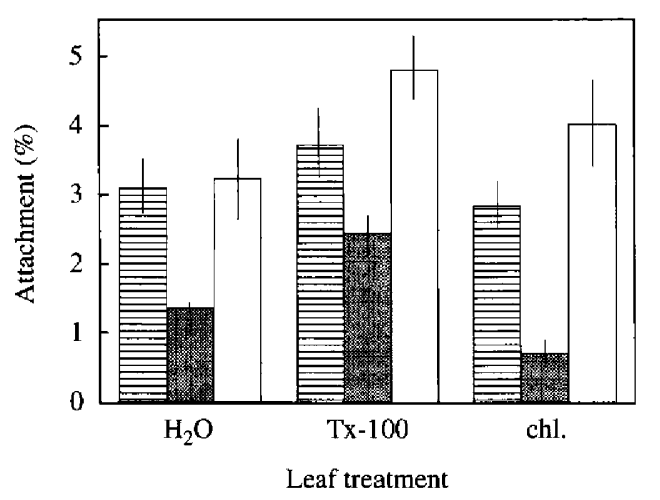

Fig. 1. Adsorption of different strains of $P$. syringae pv. syringae R32; wild-type R32 (目), non-piliated mutant R32.4 (圈), super-piliated mutant R32.13 ( $\square$ ), to the leaf-surface of bean after different treatments of the leaf. Treatments: rinsing in water $\left(\mathrm{H}_{2} \mathrm{O}\right)$, submerging in $0.1 \%$ Triton $\mathrm{X}-100$ followed by rinsing in water (Tx-100), soaking in chloroform followed by rinsing in water (chl.). Leaf disks were agitated in radioactively labelled bacterial suspension for $1 \mathrm{~h}$. The columns represent an average of six repeats with standard deviations indicated by bars.

variable wetted surface area and consequently in variability between the replicates measuring adsorption of piliated and non-piliated strains of $P$. syringae pv. syringae R32 (Fig. 1). Leaves treated in the non-ionic detergent Triton X-100 followed by extensive rinsing in water prior to the adsorption incubation were easier to use in the adsorption assay. This treatment removed air bubbles, resulting in an even wetting of the leaf surface, without water soaking the interior of the leaf. The Triton X-100 treatment had only a small effect on the average number of cells of the R32 strains that adhered (Fig. 1), and did not change the hydrophobicity of the leaf surface as determined by droplet contact angle measurements.

To remove the waxy surface layer, the leaves were treated with chloroform, followed by extensive rinsing in water. The treated leaves lost their hydrophobicity as measured by the droplet contact angle assay. Adsorption of piliated bacteria to these leaves was as efficient as adsorption to the untreated leaves, suggesting that pilusmediated attachment does not result from hydrophobic interaction of the pilus with the leaf surface wax. The low level of adsorption of the non-piliated strain R32.4 with the untreated and Triton X-100 treated leaves was further reduced by about $50 \%$ on chloroform treated leaves (Fig. 1). Thus the chloroform treatment accentuates the influence of the pilus in the adsorption process.

Piliated strains of $P$. syringae pv. syringae R32 adsorbed efficiently to the surface of bean leaves, whereas the adsorption of the non-piliated strain R32.4 remained low after extended incubation. The adsorption rate of super-piliated strain R 32.13 was twice that of the wildtype R32 during the rapid initial adsorption (Fig. 2).

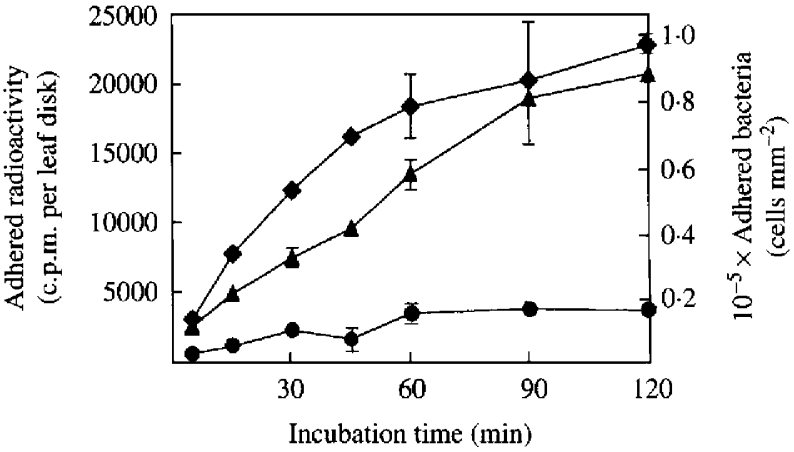

Fig. 2. Rate of adsorption of piliated $(\boldsymbol{\Delta})$, super-piliated $(\mathrm{R} 32.13, \boldsymbol{\Delta})$ and non-piliated (R32.4, - strains of $P$. syringae pv. syringae R32. Chloroform-treated leaf disks were used and the adsorption conditions were as described in Methods. Radioactivity of samples remaining after rinsing at indicated times was measured. Each point represents an average of three repeats with standard deviations indicated by vertical bars.

After $1 \mathrm{~h}$ of incubation the rate of adsorption of the super-piliated strain decreased, suggesting that binding sites on the leaf surface were gradually being saturated. However, during prolonged incubation the number of adsorbed bacteria continued to increase. When using higher concentrations of bacteria than those shown in Fig. 2, the relative adsorption rate was lower, but the number of adhered cells did not reach a specific saturation level. This may be due to the formation of clusters of bacteria binding to each other on the leaf surface, as was observed in SEM (Fig. 3).

$P$. syringae pv. phaseolicola $\mathrm{HB}$ bound preferentially to the stomata of untreated or Triton X-100-treated leaves (Fig. $3 a$ ), whereas $P$. syringae pv. syringae R32 was attached evenly over the leaf surface (Fig. $3 d$ ). For both pathovars the preference of adherence of the superpiliated strains was similar to that of the wild-types (Fig. $3 c, f)$. Treatment of the bean leaves with chloroform affected neither adhesion efficiency nor distribution of $P$. syringae pv. syringae cells (not shown), whereas the preferential localization of piliated bacterial cells of $P$. syringae pv. phaseolicola (Fig. 4a) was no longer observed on the chloroform-treated leaves (Fig. $4 b$ ).

\section{Adsorption conditions}

The influence of various divalent cations on pilusmediated adsorption was tested with super-piliated and non-piliated strains of R32 and $\mathrm{HB}$ in the standard buffer $(0.3 \times \mathrm{M} 9$ salts supplemented with $0.1 \%$ glucose $)$, and in a buffer with the phosphate salts replaced with 50 mm-Tris/ $\mathrm{HCl}$, pH 7.0 (Table 3). Adsorption of piliated strains of both R32 and HB was efficient in the absence of divalent cations. The efficiency of adsorption of $P$. syringae pv. phaseolicola decreased by about $50 \%$ 

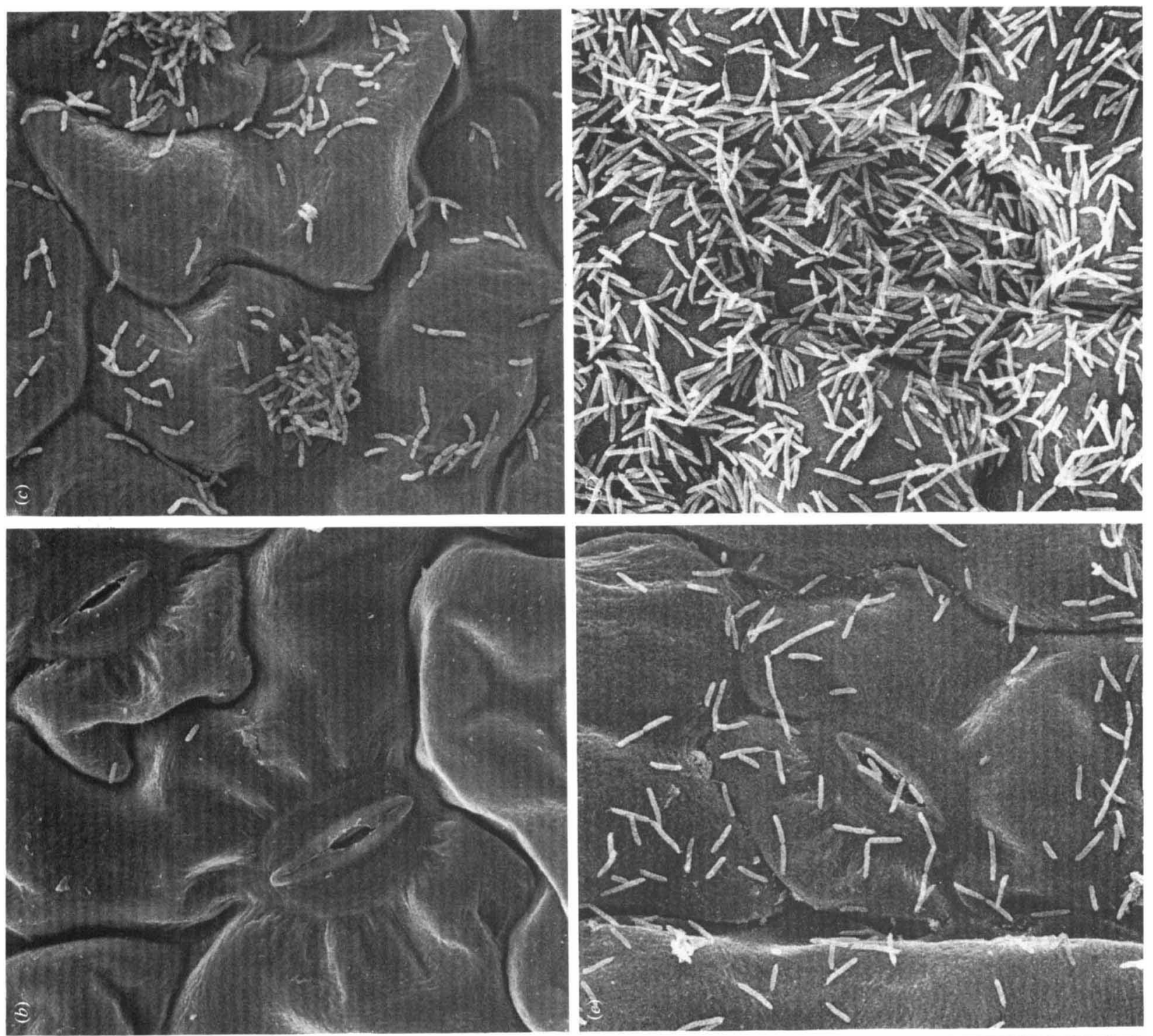

气ั

$3 \frac{a}{2}$

氖

莺

范泀

을

$\sum_{n}$

อก 華

影

苛导

<.

놀

वै\&

$\stackrel{5}{5}$

$\stackrel{\Xi}{2}$

产

它

可

号

$\pm \frac{5}{5}$

垔密

定

응

$\Xi$

옹

产

:

客焉

$\stackrel{3}{\square}$

焉

응
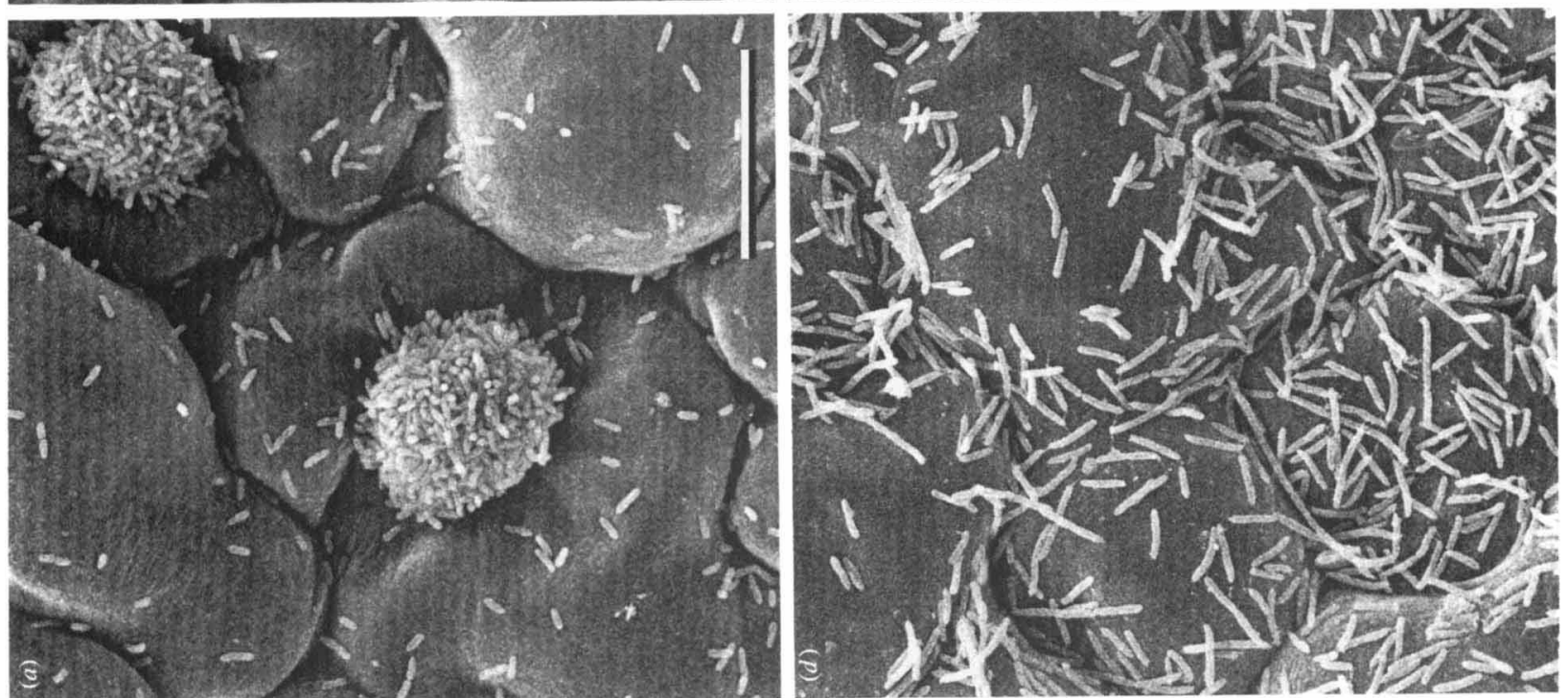

这

蛋

至

范

政

宅

ธ

结导

政

อे ले

ํㅡㄹ음

政

5

娄言

as

三最

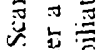

的高

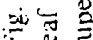



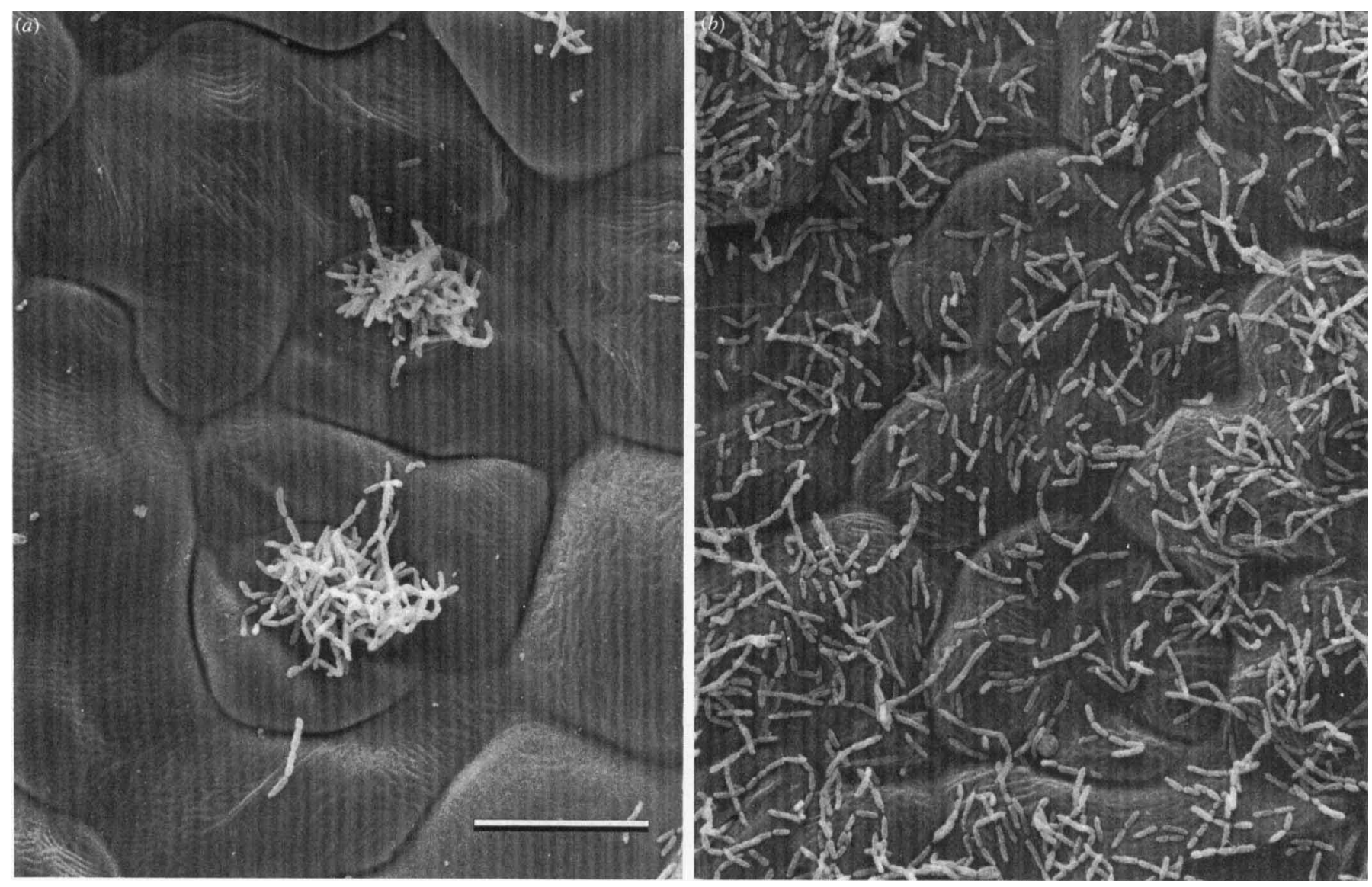

Fig. 4. Scanning electron micrographs showing the lower surface of a bean leaf after $1 \mathrm{~h}$ agitation in a suspension of $P$. syringae pv. phaseolicola ER2.5.31. The preferential adhesion of bacterial cells to stomata of untreated (not shown) and Triton X-100 treated leaves $(a)$ is not observed on chloroform-treated leaves $(b)$. Bar, $10 \mu \mathrm{m}$.

with increasing $\mathrm{MgCl}_{2}$ concentration over the range of 5-30 mM, but increased again at concentrations of $100 \mathrm{~mm}$ and above. No salt precipitation occurred at any of the concentrations of $\mathrm{MgCl}_{2}$ used. Adsorption of $P$. syringae pv. syringae $\mathrm{R} 32$ was consistently high at all concentrations of $\mathrm{MgCl}_{2}$. In all cases adsorption of nonpiliated strains remained low. The other divalent cations tested $\left(\mathrm{Ca}^{2+}\right.$ and $\left.\mathrm{Mn}^{2+}\right)$ lowered adhesion of the piliated bacteria significantly in the phosphate-containing buffer. Little $\left(\mathrm{Mn}^{2+}\right)$ or no $\left(\mathrm{Ca}^{2+}\right)$ adhesion inhibition was seen, however, when the phosphate buffer was replaced by Tris/ $\mathrm{HCl}$ buffer with the same $\mathrm{pH}$ and molarity (Table 3), suggesting that the bacterial cells were aggregated in the presence of e.g. calcium phosphate, as seen by visible aggregates in the bacterial suspension. Elevation of the ionic strength of the media with $\mathrm{NaCl}$ or the osmolarity with sorbitol had only a minor effect on adsorption (Table 3).

After an adhesion period of $60 \mathrm{~min}$ the samples were washed by shaking for $10 \mathrm{~min}$ in the washing buffer. Extension of the washing for up to $2 \mathrm{~h}$ in the washing buffer or in the standard adsorption buffer did not significantly improve the removal of the piliated bacteria, whereas sonication of the leaf disks in the washing buffer in a sonication bath detached $70 \%$ of the adsorbed piliated bacteria.

\section{Adsorption of different pathovars to host and non-host plants}

Fifteen strains from ten $P$. syringae pathovars were screened for sensitivity to the pilus-specific bacteriophage $\phi 6$. Eight of the tested strains exhibited sensitivity in a cross-streaking assay. On five of these strains the plaques were turbid using the original phage. Host-range mutants of the phage, producing clear plaques and exhibiting a high efficiency of plating, were isolated for these five strains. The host-range mutant phages were used to select phage-resistant bacterial mutants. Resistant strains tested for lack of phage-adsorption, indicating lack of pili, were compared to the wild-type strains in plant leaf adsorption assays with chloroformtreated host and non-host plant leaves for each bacterium. HB (pil ${ }^{-}$mutant ER2.5 and the complemented 
Table 3. Adsorption of bacteria to the bean leaf-surface in different media

\begin{tabular}{|c|c|c|c|c|c|c|}
\hline \multirow{2}{*}{$\begin{array}{l}\text { Adsorption } \\
\text { medium* }\end{array}$} & & & \multicolumn{4}{|c|}{ Adsorbed bacteria $\left(10^{4}\right.$ cells $\left.\mathrm{mm}^{-2}\right) \dagger$} \\
\hline & \multicolumn{2}{|c|}{ Supplement } & ER2.5.31 & ER2.5 & $\mathrm{R} 32.13$ & $\mathrm{R} 32.4$ \\
\hline \multirow[t]{9}{*}{ Tris $/ \mathrm{HCl}$} & None & & $2 \cdot 46 \pm 0 \cdot 60$ & $0 \cdot 30 \pm 0 \cdot 12$ & $5 \cdot 09 \pm 1 \cdot 32$ & $1.67 \pm 0.40$ \\
\hline & $\mathrm{MgCl}_{2}$ & $1 \mathrm{~mm}$ & $2 \cdot 90 \pm 1 \cdot 22$ & $0.24 \pm 0.02$ & $4.79 \pm 2.02$ & $0.89 \pm 0.23$ \\
\hline & $\mathrm{MgCl}_{2}$ & $5 \mathrm{mM}$ & $1.56+0.30$ & $0.21 \pm 0.08$ & $5.57 \pm 2.50$ & $0.76 \pm 0.11$ \\
\hline & $\mathrm{MgCl}_{2}$ & $10 \mathrm{~mm}$ & $1 \cdot 41 \pm 0-43$ & $0.23 \pm 0.02$ & $5.59 \pm 0.99$ & $0.62 \pm 0.08$ \\
\hline & $\mathrm{MgCl}_{2}^{2}$ & $30 \mathrm{~mm}$ & $1 \cdot 29 \pm 0.32$ & $0.19 \pm 0.11$ & $4.02 \pm 1.72$ & $0.48 \pm 0.21$ \\
\hline & $\mathrm{MgCl}_{2}$ & $100 \mathrm{~mm}$ & $2.87 \pm 0.78$ & $0.65 \pm 0.01$ & $3 \cdot 81 \pm 0 \cdot 70$ & $0 \cdot 65 \pm 0.21$ \\
\hline & $\mathrm{MgCl}_{2}$ & $200 \mathrm{~mm}$ & $3 \cdot 63 \pm 0 \cdot 31$ & $0.54 \pm 0.05$ & $4.07 \pm 1.59$ & $1.14 \pm 0.16$ \\
\hline & $\mathrm{CaCl}_{2}$ & $5 \mathrm{mM}$ & $3 \cdot 16 \pm 0 \cdot 17$ & $0 \cdot 29 \pm 0.13$ & $5 \cdot 46 \pm 0.63$ & $1.62 \pm 0.72$ \\
\hline & $\mathrm{MnCl}_{2}^{2}$ & $5 \mathrm{mM}$ & $0.95 \pm 0.27$ & $0 \cdot 22 \pm 0 \cdot 14$ & $3 \cdot 76 \pm 0.36$ & $0 \cdot 86 \pm 0 \cdot 16$ \\
\hline \multirow[t]{10}{*}{ Standard } & None & & $2 \cdot 70 \pm 0 \cdot 49$ & $0 \cdot 26 \pm 0 \cdot 01$ & & \\
\hline & $\mathrm{MgCl}_{2}$ & $100 \mathrm{~mm}$ & $2.78 \pm 0.06$ & $0.34 \pm 0-02$ & & \\
\hline & $\mathrm{MgSO}_{4}$ & $5 \mathrm{~mm}$ & $1 \cdot 27 \pm 0.04$ & $0 \cdot 40 \pm 0 \cdot 02$ & & \\
\hline & $\mathrm{MgSO}_{4}$ & $100 \mathrm{~mm}$ & $2.93 \pm 0.27$ & $0.23 \pm 0.02$ & & \\
\hline & $\mathrm{CaCl}_{2}{ }^{-}$ & $1 \mathrm{~mm}$ & $0-73 \pm 0.13$ & $0-33 \pm 0-07$ & & \\
\hline & $\mathrm{CaCl}_{2}^{2}$ & $5 \mathrm{mM}$ & $0.24 \pm 0.15$ & $0.13 \pm 0.04$ & & \\
\hline & $\mathrm{MnCl}_{2}$ & $5 \mathrm{mM}$ & $0.17 \pm 0.02$ & $0.13 \pm 0.03$ & & \\
\hline & $\mathrm{NaCl}^{2}$ & $500 \mathrm{mM}$ & $2.13 \pm 0.01$ & ND & & \\
\hline & $\mathrm{NaSO}_{4}$ & $100 \mathrm{~mm}$ & $2.68 \pm 0.03$ & $0 \cdot 28 \pm 0.04$ & & \\
\hline & Sorbitol & $500 \mathrm{~mm}$ & $1.82 \pm 0.03$ & $\overline{\mathrm{ND}}$ & & \\
\hline
\end{tabular}

* Media and adsorption conditions were as described in Methods, but cells were added to $1 \times 10^{7}$ cells ml ${ }^{-1}$. Chloroform-treated leaves were used.

$\dagger$ Mean and standard deviation respectively of three repeats.

ND, Not determined.

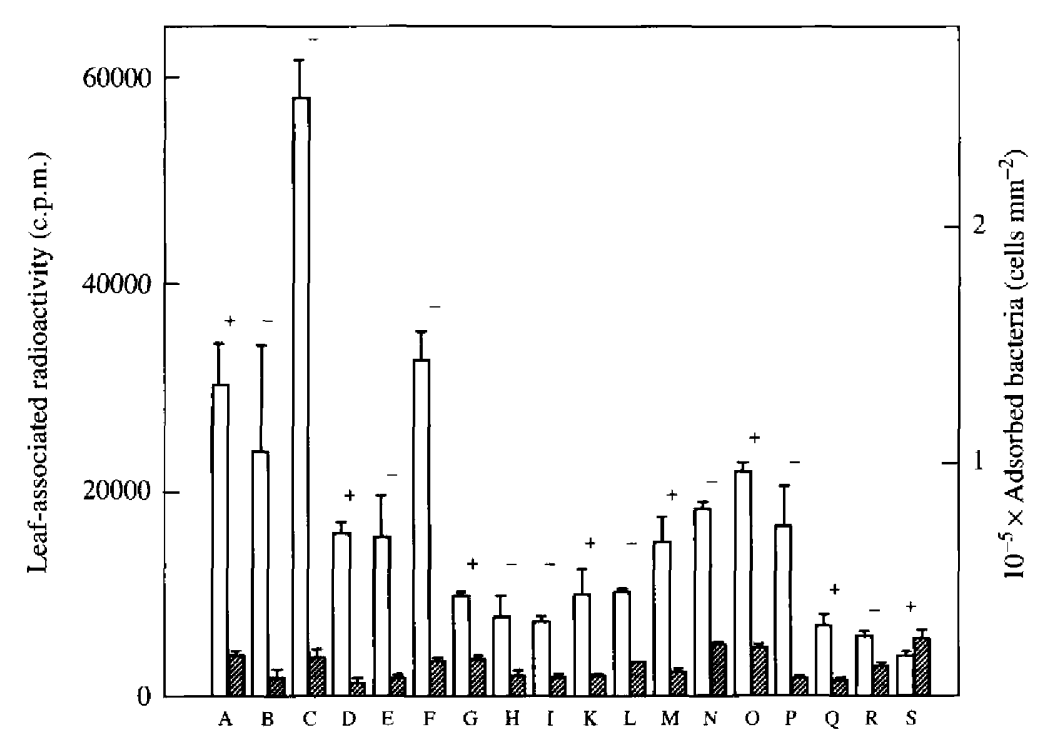

Fig. 5. The adsorption rate of piliated strains ( $\square$ ) and non-piliated derivatives (12) of various pathovars of $P$. syringae to host plants (indicated by + above the column) and non-host plants (above the column) was measured using radioactively labelled bacteria and chloroform-treated leaf disks in the standard adsorption assay with a $1 \mathrm{~h}$ incubation period. $P$. syringae pv. syringae R32.13 ( $\mathrm{pil}^{++}$) and R32.4 (pil $\left.{ }^{-}\right)$on bean (A), tomato (B) and cucumber (C); pv. phaseolicola ER2.5.31 (pil ${ }^{++}$) and ER2.5 (pil $)$, on bean (D), tomato (E) and cucumber (F). The other pathovars were represented by the wild-type and a nonpiliated $\phi 6$-resistant mutant: pv. phaseolicola 2740 on bean $(\mathrm{G})$ and tomato $(\mathrm{H})$; pv. tomato 2841 on bean (I) and tomato (K); pv. tomato 9315 on bean (L) and tomato (M); pv. lachrymans 829 on bean $(\mathrm{N})$ and cucumber $(\mathrm{O})$; pv. coronafaciens 3113 on bean (P) and oats (Q); pv. syringae 457 on bean $(\mathrm{R})$ and apple (\$). Each column is the average of at least three repeats. The standard deviation is indicated by bars. pil $^{++}$-derivative ER2.5.31) and R32 (pil ${ }^{-}$mutant R32.4 and $\mathrm{pil}^{++}$mutant $\mathrm{R} 32.13$ ) were adsorbed to the host bean plant and to two non-host plants, tomato and cucumber. The other strains were adsorbed to two plants; bean and the respective host-plant, or in the case of the P. syringae pv. phaseolicola 2740 , bean (host) and tomato.

In all cases except one, adsorption to both susceptible and non-susceptible host leaves was lower by a factor of two to five for the non-piliated mutant strain compared to the wild-type (Fig. 5). Pseudomonas syringae pv. syringae strain 457 , pathogenic on apple exhibited a relatively low adhesion efficiency despite $\phi 6$ sensitivity. Also the original $\phi 6$ host $P$. syringae pv. phaseolicola HB10Y exhibits only twice the adhesion efficiency of the non-piliated mutant, whereas super-piliated spontaneous mutants (Romantschuk \& Bamford, 1986) adsorb about 
as efficiently as strain ER2.5.31. Each of the piliated parental strains bound approximately equally well to the leaves of the non-host leaf surface as to the leaves of their respective host plant (Fig. 5). However, adsorption to cucumber was somewhat higher for both the bean pathogens and the cucumber pathogen $P$. syringae pv. lachrymans. Oats, on the other hand, remained hydrophobic even after the chlorofrom treatment; consequently $P$. syringae pv. coronafaciens adsorbed with a higher efficiency to the non-host bean leaf than to the oat leaf. In all, adsorption correlated to the presence of $\phi 6$ specific bacterial pili, and to type of leaf, but not to host-pathogen relationship, suggesting that binding is non-host-specific.

When the strains were tested for pathogenicity or induction of the hypersensitive response by infiltrating leaf tissue no difference could be observed between the $\phi 6$ resistant strains and the wild-type strains.

The tested strains include both motile and non-motile strains (Table 1). In general, adhesion of motile strains was better than that of non-motile ones, but the relative decrease in adhesion of the non-piliated mutants was not dependent on motility, Thus, the positive effect of motility on adhesion is probably due to a higher chance of impact due to vigorous movement by the bacterial cells. Whether this motility is chemotactic, and thus directed towards a plant attractant, is not known.

\section{Discussion}

Attachment of $P$. syringae to plant surfaces correlates with the ability of the bacterium to adsorb phage $\phi 6$. Attachment of phage-resistant non-piliated mutants to the leaf surface is lowered by a factor of between two and ten compared to the piliated parental strain, whereas variants adsorbing phage more efficiently than the wildtype, i.e. expressing an elevated number of pili exhibit a higher rate of leaf attachment than the wild-type.

Non-piliated mutants of $P$. syringae pv. phaseolicola HB10Y were earlier shown to adsorb less efficiently and to cause disease symptoms less frequently in certain conditions than piliated mutants or the wild-type strain (Romantschuk \& Bamford, 1986). The role of the pilus in the plant adsorption process was here confirmed by the simultaneous recovery of $\phi 6$ sensitivity, phage adsorption and plant adsorption ability of non-piliated HB mutants, using a complementing cosmid.

The preferential attachment of $P$. syringae pv. phaseolicola $\mathrm{HB} 10 \mathrm{Y}$ cells to stomata, which was not observed in $P$. syringae pv. syringae R32, would suggest that they recognize different plant receptors. In analogy with the fimbriae of enteropathogenic bacteria such as uropathogenic strains of $E$. coli (Jann \& Jann, 1990), the adhesin of $P$. syringae may consist of a minor protein located at the tip of the filament. The bulk of the filament in the two pathovars may thus be identical with a difference only in the adhesin protein. The pilus was suggested to be in contact with the leaf surface at its tip (Romantschuk \& Bamford, 1986). Surprisingly the adhesion of piliated bacteria remained about the same regardless of leaf treatment. This was also true for piliated strains of $P$. syringae pv. phaseolicola $\mathrm{HB}$ although the preferential localization of the cells at the stomata was not observed on chloroform-treated leaf surfaces. The fact that bacterial cells are able to attach to each other forming clusters on the leaf surface in the absence of free binding sites may account for this lack of difference.

The role of the flagellum of R32 in the distribution of the bacterial cells on the leaf surface is not known. However, preliminary results using motile strains of $P$. syringae pv. phaseolicola show a distribution similar to that of the non-motile $P$. syringae pv. phaseolicola strain $\mathrm{HB}$, supporting the role of the pilus rather than the flagellum in the specificity of attachment. The fact that the preference of $P$. syringae pv. phaseolicola for stomata was not observed with the chloroform-treated leaf surface can be interpreted in more than one way. Removal of the waxy surface layer of the leaf may expose previously embedded receptors. Alternatively, the surface tension of the bacterial suspension and the hydrophobicity of the leaf surface may permit access of the HB cells only at the stomata until this hydrophobicity is reduced by chloroform treatment. Hydrophobicity does not, however, limit the distribution of the motile strain $\mathrm{R} 32$. Whether the flagellum per se or the motility of R32 is a factor that lowers surface tension or whether R32 produces a surface active agent as suggested for certain Pseudomonas spp. (Bunster et al., 1989) is not known. The efficient attachment of piliated strains HB and R32 to the chloroform-treated leaves suggests that pilusmediated attachment does not result from a hydrophobic interaction of the pilus with cuticular waxes of the leaf surface. The low level of attachment of the non-piliated strains that was reduced further by chloroform treatment may result from hydrophobic interactions of the type suggested by Fett (1985).

For seven out of the eight different $\phi 6$-sensitive $P$. syringae strains and pathovars used in this study, elimination of pili was correlated with a significant reduction in adherence of bacterial cells to leaf surfaces of both host and non-host plants; thus pilus-mediated adhesion appears not to be host-specific. Similarly Jasalavich (1987) found efficient adhesion of $P$. syringae pv. lachrymans and pv. tomato to the surface of both cucumber and tomato.

The rate of adhesion was relatively insensitive to cell density. Even after prolonged incubation of the leaf disks 
with bacteria, continued increase in rate of adhesion was apparent. Although this may reflect an absence of distinctive saturable receptors, it may also reflect the ability of the bacteria to form clusters of cells sticking to each other on the leaf surface after prolonged incubation. Such clusters have also been observed with Agrobacterium and Rhizobium binding to plant cell walls (Matthysse, 1983) or root hair tips (Smit et al., 1989; Smith \& Stacey, 1990). With these bacteria, cluster formation was linked to production of bacterial cellulose and/or to aggregation by plant lectins.

In the experiments characterizing factors influencing pilus-mediated adsorption, strains over-expressing pili $(P$. syringae $\mathrm{pv}$. syringae $\mathrm{R} 32.13$ and $P$. syringae $\mathrm{pv}$. phaseolicola ER2.5.31) were used, both because these strains are more easily monitored in the adsorption assays, and because the presence of pili in the wild-type strains is affected by environmental conditions. Thus, wild-type $P$. syringae pv. phaseolicola cells do not adsorb phage in the presence of sodium azide and other uncoupling agents suggesting that the pilus is retracted in the absence of a membrane potential (Romantschuk \& Bamford, 1985; Romantschuk et al., 1988). This effect was not observed in phage-resistant super-piliated strains used (M. Romantschuk, unpublished).

In a comparison of the two bean pathogens $P$. syringae pv. phaseolicola $\mathrm{HB} 10 \mathrm{Y}$ and $P$. syringae pv. syringae R32, differences were observed in attachment efficiency and localization of bacterial cells adhering to the leaf surface, whereas very little difference was seen in dependence on adsorption conditions. Magnesium was neither necessary for adsorption, nor inhibitory even at high concentrations. Other divalent cations affected the adsorption strongly in the presence of phosphate but not in Tris/ $\mathrm{HCl}$ buffer. The apparent inhibition evidently resulted from aggregation of bacteria. Raising the ionic strength with $\mathrm{NaCl}$ did not significantly inhibit adsorption, arguing against a role for electrostatic forces in the pilus-mediated interaction.

Various strains of the bacterium $P$. syringae, pathogenic as well as non-pathogenic, exhibit a capacity to grow epiphytically on plants without causing disease (Hirano \& Upper, 1983). P. syringae is able to colonize the surfaces of both susceptible and resistant plants, although a higher epiphytic population density reportedly can be maintained on susceptible plants (Daub \& Hagedorn, 1981). Bacteria in the epiphytic growth phase form a potential inoculum for disease when suitable conditions occur, and for spreading inoculum from resistant to susceptible plants (Ercolani et al., 1974). Considering that many foliar plant pathogenic bacteria exhibit an epiphytic growth phase, and that the opportunistic pathogen $P$. syringae is common on the surface of symptomless plants, it seems likely that this is the phase where the pilus-mediated attachment described here plays a role. This pilus-mediated attachment was host-independent, which is consistent with the non-hostspecific nature of epiphytic growth. Attachment on plant surfaces may thus be a fitness factor for epiphytic bacteria in a rather unspecific manner, anchoring bacterial cells to a solid support in an ecologically favourable location. Testing and confirmation of adhesion ability as an epiphytic fitness factor under field or microcosm conditions remains to be done.

This work was supported by the Foundation for Biotechnology and Fermentation Research (M.R., E. R.). Additional support was obtained from the Ministry of Agriculture and Forestry of Finland and by the Kemira Oy foundation. Steven Lindow and Mark Wilson are acknowledged for helpful suggestions and Jenni Penttilä for excellent technical assistance.

\section{References}

Bamford, D. H., Palva, E. T. \& LounatmaA, N. (1976). Ultrastructure and life cycle of the lipid containing bacteriophage $\phi 6$. Journal of General Virology 32, 249-259.

Blakeman, J. P. (1991). Foliar plant pathogens: epiphytic growth and interactions on leaves. Journal of Applied Bacteriology Symposium Supplement 70, 49S-59S.

Blakeman, J. P. \& Fokkema, N. J. (1982). Potential for biological control of plant diseases on the phylloplane. Annual Review of Phytopathology 20, 167-192.

Bunster, L. L., Fokkema, N. J. \& Schippers, B. (1989). Effect of surface-active Pseudomonas spp. on leaf wettability. Applied and Environmental Microbiology 55, 1340-1345.

ButTerworth, J. \& MCCARTNEy, H. A. (1991). The dispersal of bacteria from leaf surfaces by water splash. Journal of Applied Bacteriology 71, $484-496$.

Cuppels, D. A., Vidaver, A. K. \& van Etten, J. L. (1979). Resistance to bacteriophage $\phi 6$ by Pseudomonas phaseolicola. Journal of General Virology 44, 493-504.

DaLb, M. E. \& HagedorN, D. J. (1981). Epiphytic population of Pseudomonas syringae on susceptible and resistant bean lines. Phytopathology 71, 547-551.

Ehrenshat, M. \& Mills, D. (1985). Construction of a cosmid clone library of Pseudomonas syringae pv. phaseolicola and isolation of genes by functional complementation. Applied and Environmental Microbiology 50, 169-171.

Ercotant, G. L., Hagedorn, D. J., Kelman, A. \& Rand, R. E. (1974). Epiphytic survival of Pseudomonas syringae on hairy vetch in relation to epidemiology of bacterial brown spot of bean in Wisconsin. Phytopathology 64, 1330-1339.

FETT, W. F. (1985). Relationship of bacterial cell surface hydrophobicity and charge to pathogenicity, physiological race, and immobilisation in attached soybean leaves. Phytopathology 75, 1414-1418.

HaAhtela, K., TarkKa, E. \& Korhonen, T. K. (1985). Type-I fimbriae mediated adhesion of enteric bacteria to grass roots. Applied and Environmental Microbiology 49, 1182-1185.

Hirano, S. S. \& UPPER, C. D. (1983). Ecology and epidemiology of foliar bacterial plant pathogens. Annual Review of Phytopathology 21, 243-269.

HirANo, S. S., BAKer, S. L. \& UpPER, C. D. (1991). Population biology of Pseudomonas syringae in the phyllosphere. In Book of Abstracts: Pseudomonas. Third International Symposium on Pseudomonads, Biology and Biotechnology. Miramare-Grignano, Trieste, Italy, June $16-20,1991$.

JANN, K. \& JANN, B. (eds) (1960). Baclerial adhesins. Current Topics of Microbiology and Immunology no. 151. Berlin \& Heidelberg: Springer Verlag. 
JASALAVICH, C. A. (1987). Attachment of the epiphytic bacteria Pseudomonas syringae pathovar lachrymans and pathovar glycinea to host and non-host leaf surfaces. PhD thesis, University of WisconsinMadison.

KnNG, E. O., WARD, M. K. \& RaneY, D. E. (1954). Two simple media for the demonstration of pyocyanin and fluorescein. Journal of Laboratory and Clinical Medicine 44, 301-307.

Lindemann, J., Constantinidou, H. A., Barchett, W. R. \& UpPer, C. D. (1982). Plants as the source of airborne bacteria, including ice nucleation-active bacteria. Applied and Environmental Microbiology 44, 1059-1063.

Lindow, S. E. (1983). The role of bacterial ice nucleation in frost injury to plants. Annual Review of Phytopathology 21, 363-384.

LINDOw, S. E. (1986). Strategies and practice of biological control of ice nucleation active bacteria on plants. In Microbiology of the Phyllosphere, pp. 293-311. Edited by N. J. Fokkema \& J. van den Heuvel. Cambridge: Cambridge University Press.

Malvick, D. K. \& MoORE, L. W. (1988). Survival and dispersal of a marked strain of Pseudomonas syringae in a maple nursery. Plant Pathology 37, 573-580.

Makı, L. R., Galyon, E. L., Chang-Chien, M. \& Caldwell, D. R (1974). Ice nucleation induced by $P_{\text {seudomonas syringae. Applied }}$ Microbiology 28, 456-460.

MatThysse, A. G. (1983). Role of bacterial cellulose fibrils in Agrobacterium tumefaciens infections. Journal of Bacteriology 154, $906-915$.

MATthysse, A. G. (1987). Characterization of non-attaching mutants of Agrobacterium tumefaciens. Journal of Bacteriology 169, 313-323.

Nurmiaho-Lassila, E. L., Rantala, E. \& Romantschuk, M. (1991). Pilus-mediated adsorption of Pseudomonas syringae to the surface of bean leaves. Micron Microscopica Acta 22, 71-72.

O'BRIEN, R. D. \& LINDOw, S. E. (1989). Effect of plant species and environmental conditions on epiphytic population sizes of Pseudomonas syringae and other bacteria. Phytopathology 79, 619-627.

Olkkonen, V. M. \& Bamford, D. H. (1987). The nucleocapsid of the lipid-containing double-stranded RNA bacteriophage $\phi 6$ contains a protein skeleton consisting of a single polypeptide species. Journal of Virology 61, 2362-2367.

RomantsCHUK, M. (1992). Attachment of plant pathogenic bacteria to the surface of plants. Annual Review of Phytopathology 30, 325-343.
ROMANTSCHUK, M. \& BAMFORD, D. H. (1981). ф6-resistant phageproducing mutants of Pseudomonas phaseolicola. Journal of General Virology 56, 287-295.

ROMANTSCHUK, M. \& BAMFORD, D. H. (1985). Function of pili in bacteriophage $\phi 6$ penetration. Journal of General Virology $\mathbf{6 6}$, 2461-2468.

RomantsCHUK, M. \& BAMFORD, D. H. (1986). The causal agent of halo blight in bean, Pseudomonas syringae pv. phaseolicola, attaches to stomata via its pili. Microbial Pathogenesis 1, 139-148.

Romantschuk, M., Olkkonen, V. M. \& Bamford, D. H. (1988). The nucleocapsid of bacteriophage $\phi 6$ penetrates the host cytoplasmic membrane. EMBO Journal 7, 1821-1829.

Sambrook, J., Fritsch, E. F. \& Maniatis, T. (1989). Molecular cloning : a Laboratory Manual, 2nd edn. Cold Spring Harbor, NY: Cold Spring Harbor Laboratory.

Selvaraj, G. \& IYER, V. N. (1983). Suicide plasmid vehicles for insertion mutagenesis in Rhizobium meliloti and related bacteria. Journal of Bacteriology 156, 1292-1300.

SMIT, G. \& STACEY, G. (1990). Adhesion of bacteria to plant cells: role of specific interaction versus hydrophobicity. In Microbial Cell Surface Interaction, pp. 179-210. Edited by R. J. Doyle \& M. Rosenberg. Washington, DC: American Society for Microbiology.

Smtt, G., Logman, T. J. J., Boerrigter, M. T. E. I., KiJne, J. W. \& LUGTENBERG, B. J. J. (1989). Purification and partial characterisation of the $\mathrm{Ca}^{2+}$ dependent adhesin from Rhizobium legominosarum biovar viciae, which mediates the first step in attachment of Rhizobiaceae to plant root hair tips. Journal of Bacteriology 171, $4054-4062$.

UPPER, C. D. (1991). Manipulation of the microbial communities in the phyllosphere. In Microbial Ecology of the Leaves, pp. 451-463. Edited by H. Andrews \& S. S. Hirano. New York: Springer Verlag.

VIDAVER, A. K., KOSKI, R. K. \& VAN ETTEN, J. L. (1973). Bacteriophage $\phi 6$ : a lipid-containing virus of Pseudomonas phaseolicola. Journal of Virology 11, 799.805.

Warren, G. \& Wolber, P. (1991). Molecular aspects of microbial ice nucleation. Molecular Microbiology 5, $239-243$.

Young, D. H. \& Sequeira, L. (1986). Binding of Pseudomonas solanacearum fimbriae to tobacco leaf cell walls and its inhibition by bacterial extracellular polysaccharides. Physiological and Molecular Plant Pathology 28, 393-402. 